\title{
CONCEPTUAL DESIGN OF MARS LANDER WITH NOVEL IMPACT INTRIGUING SYSTEM
}

\author{
Malaya Kumar Biswal $\mathbf{M}^{\star}$ and Ramesh Naidu Annavarapu ${ }^{\dagger}$
}

\begin{abstract}
Planetary landing is the ultimate principle of extraterrestrial exploration. But effectuating successful landing is a strenuous assignment because lander may experience a malfunction and can perform defective landing at any stage due to numerous factors. Here from the perspective of inefficient impact attenuator, we propose a design of Mars lander with a novel impact absorber fabricated from alloyed silicon-chromium spring damper integrated with a dual cylinder of distinct diameter to counteract the pressure variance exerted during landing. In addition to this, we have reviewed the past landing missions and discussed the approach to design and fabrication. Finally, from the derived formulations, we have displayed the preliminary results and we expect that the attenuator may bear an impact force of 20-140 kN for grounding 0.2-1.0-ton class crewed or cargo landers on Mars.
\end{abstract}

\section{INTRODUCTION}

Landing robotic spacecraft and humans on Mars has become one of the inevitable technological necessities for humans to enable planetary exploration beyond low earth orbit. Effectuating perfect Mars expedition requires landing of enormous cargoes, crewed modules, ascent vehicles, and scientific laboratories on Mars. But, a crash landing can destruct the whole landing scenario due to lack of adequate impact absorbers. And, the existence of deformable shock absorbers like Aluminium honeycomb and carbon fibres within landing gears of earlier landers are defeasible for large-scale mass and crewed landing. Further in the EDL scenario, switching of events during EDL sequence within a limited span of 5 to 8 minutes appears to be the most challenging task for landers. Scrutinizing these concerns, we propose a novel impact intriguing system that will be more achievable and sustainable for extensive landing missions. In this paper, we have discussed the materialistic and fabrication approach for the conceptual design of impact attenuator for high mass Mars landers. Impact attenuator is designed utilizing alloyed silicon chromium spring damper (with a tensile strength of 2010-2060 MPa) integrated with the dual hydraulic cylinder of distinct diameter (filled with mineral oil with a density range from $0.8-0.9 \mathrm{~g} / \mathrm{mol}$ ) to counteract pressure variance. This attenuator is capable of bearing an impact force of approximately 20-140 $\mathrm{kN}$ for a $0.2-1.0$-ton class Mars landers dropped from a height of $10 \mathrm{~m}$ with an acceleration of $3.71 \mathrm{~m} / \mathrm{s}$ (at Mars). Additionally, we have reviewed the impact attenuation system of past landers and its implications thereby comprehensively summarizing EDL parameters of all Mars landers. Subsequent to design, the appropriate mathematical formulation was made employing the work-

\footnotetext{
* Graduate Researcher, Department of Physics, Pondicherry University, Kalapet, Puducherry - 605 014, India. Student Member of AIAA and Indian Science Congress Association, India.

${ }^{\dagger}$ Associate Professor, Department of Physics, Pondicherry University, Kalapet, Puducherry - 605 014, India.
} 
energy principle. From the results, we have discussed and recommended this kind of impact attenuator for high mass Mars and cargo landers to effectuate soft-landing in forthcoming missions. Moreover, to endorse effective landing, we also discussed the potential of inflatable aerodynamic decelerators and orbital entry for rapid deceleration and aerocapture to minimize the impact force at touchdown. The prime intent of this paper is to protect the lander modules and their instruments over the defective landing.

\section{EARLIER MARS LANDER MISSION}

The pioneer attempt to touch the red planet begins with the historic launch of lander $2 \mathrm{MV}-3$ No.1 onboard Molniya that endured failure and destroyed in LEO due to launch vehicle concerns. Besides this misfortune, Soviet Union re-attempted Mars $2 \& 3$ landers whereas Mars 2 remained ineffective and Mars 3 lasted for 20 seconds of data transmission after landing. Alike Mars $2 \& 3$, Russian again re-attempted to land on Mars with Mars 5, $6 \& 7$, but entire effort lasted disappointment as Mars 6 malfunctioned and Mars 7 missed the planet before atmospheric entry. In 1975, the United States first landing attempt with twin Viking landers (Viking $1 \&$ 2) performed extraordinary landing with successful mission accomplishment. Aspiring to explore Martian moons, Soviet Union strived dual Phobos mission each comprising of orbiter and lander, but both missions encountered radio communication issues. The advancement of new EDL technology (i.e., parachute deployment and airbag landing system) made the US achieve second landing (Mars Pathfinder-1966) which deployed a mini-rover and Mars Phoenix lander in 2007. Subsequent lander missions like the collapse of Russian's Mars 96 caused by upper-stage booster malfunction, Mars Polar lander loss as a consequence of communication issues (References 1 and 2).

In the controversy of the Mars expedition, ESA (Europe) comes into execution with its first landing endeavour (Beagle 2 lander) that enforced effective landing but unintentionally obscured communication loss. Their effort pursued with second landing attempt (Schiaparelli EDM) which achieved successful hypersonic atmospheric entry into the Martian atmosphere but shortly, premature deployment of parachute made it crash on the surface. Having upgraded Viking era technology, the United States successfully landed InSight Mars lander in November 2018 and it continues its surface operation on Mars. Some of the failed landers are listed below in Table 1 .

Table 1. Crashed Landers.

\begin{tabular}{l|l|l}
\hline Lander & Issue & Results \\
\hline Mars 2 Lander & Improper atmospheric entry & Crashed on the surface \\
\hline Mars Polar Lander & Lost communication before touchdown & Failed \\
\hline Deep Space 2 Penetrator & Lost with Mars Polar Lander & Failed \\
\hline Schiaparelli EDM & Faulty gyroscope damaged guidance control system & Crashed on the surface \\
\hline
\end{tabular}

\section{LANDING CHALLENGES AND PROSPECT}

For dynamic landing, the lander has to confront distinct challenges such as the thickness of the Mars atmosphere, low surface elevation, limited EDL period, and surface hazards which include distribution of large seized rocks, valleys, terrains and robust dust storms. Especially for legged landers have rock hazards as their largest challenge (Reference 3). Crushable bumper landers having aluminium honeycomb, foam plastic, airbags, and crushable carbon fibres (Reference 4). And they don't have to contemplate surface hazards but competent aerodynamic deceleration due to mass constraints (i.e., 0.6 ton). In the conception of future manned lander missions, it is quite 
requisite to ground large masses, and on other hand factors such as the diameter of aeroshell \& parachute and ballistic coefficient are restrained. To execute effective human class Mars mission with extended traditional EDL technology mass constraints extended from 0.6 ton to 25 tons (Reference 5) and it may yield more impact force upon landing. Hence our novel impact intriguer may sustain effective touchdown.

Table 2. Past Landers and their Impact Attenuators (Reference 6).

\begin{tabular}{l|l|l}
\hline Attenuator & Mars Lander & Lander Mass (kg) \\
\hline Foam Plastic & Mars 2,3,6,7, Phobos 1,2 & $358-635$ \\
\hline Aluminium Honeycomb & Viking 1,2 & $423-590$ \\
\hline Air-Bags & MPF, Mars96, Beagle 2 & $30-360$ \\
\hline Crushable Materials & Phoenix, Schiaparelli, Insight & $280-360$ \\
\hline Inflatable Ballute & Deep Space 2 & 4.5 \\
\hline
\end{tabular}

\section{DESIGN METHODOLOGY AND WORKING}

\section{Design Methodology}

The conceptual design of Mars lander has a lander base comprises of eight landing legs, both (four interior hydraulic legs) and (four exterior novel impact landing legs). Each leg comprising of primary attenuator with a spring-damper and secondary attenuator with a hydraulic damper. The primary attenuator incorporates a spring holder and a helical compression spring as well as a secondary attenuator incorporates a hydraulic cylinder and a piston rod. Moreover, the hydraulic cylinder divides into the upper and lower compartment where the upper compartment is loaded with compressed oil and air that are the best adoptive method for landers. The internal portion of the upper compartment has a mounted control valve to release the hydraulic fluid and a pressure sensor to indicate pressure range to control valve. The function of the sensor is to signal the sensor to open and gradually exempt hydraulic fluid when the pressure exceeds beyond a predetermined level. Conclusively total setup is confined within a retractable cylinder which completes the entire lander leg setup.

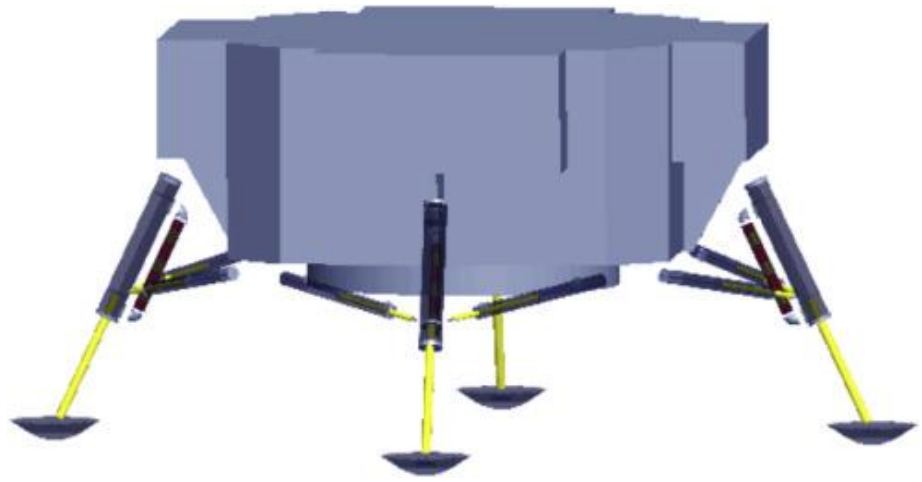

Figure 1. Typical Design of Lander Base with Four Exterior Legs. Image Courtesy: Chen Wang-2019. 


\section{MODELLING OF LANDER LEG}

\section{Primary Unit}

The primary unit has high tensile $\mathrm{Si}-\mathrm{Cr}$ helical compression spring as a principal shock absorber. The spring is wrapped inside a retractable cylinder coupled structure of appropriate diameter. The geometry of spring relies on spring constant that ultimately depends on the lander mass, the vertical distance from where the lander gets dropped, and the terminal velocity. The logic behind the use of spring-damper as principal shock attenuator is due to the expeditious nature of impact absorption exerted during ground touchdown.

\section{Secondary Unit}

The primary unit is integrated with a hydraulic damper and that forms a secondary unit. The hydraulic systems absorb the shock with the help of a hydraulic accumulator attached to that system. Here, the basis of utilizing hydraulic damper as an auxiliary shock absorber is due to the nature of rapid energy absorption (exerted by the spring) and moderate energy dissipation.
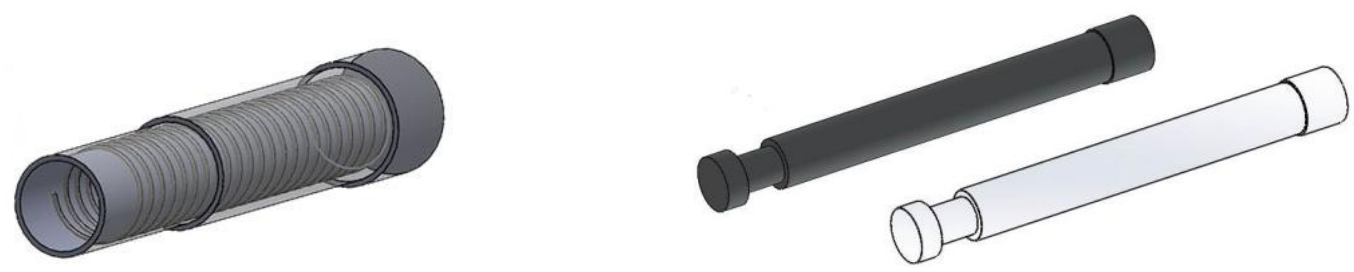

Figure 2. Primary and Secondary Hydraulic Legs.

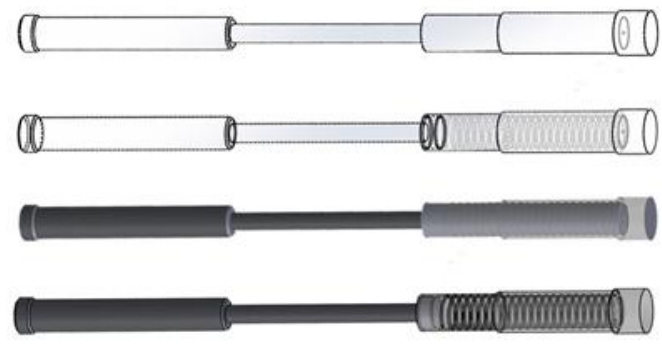

Figure 3. Design of Exterior Lander Leg.

\section{WORKING OF LANDER WITH IMPACT ATTENUATOR}

During the interim of the landing phase, after the halt of retrorockets, the lander gets dropped from a certain altitude, and the lander contacts the ground from a vertical direction. It gets subjected to vertical impact now the spring damper inside primary attenuator starts working and gets pressed downwards, the maximum impact gets absorbed by the spring and stores in the form of mechanical energy. After a short layoff, it transfers the same energy to secondary attenuator obeying newton's second law.

Secondary attenuator encounters maximum impact which in turn makes its piston to move upwards so that the hydraulic damper can obsess and dissipate maximal impact. Relatively, some small amount of hydraulic fluid will move from upper to the lower compartment. In case of excess hydraulic pressure, a pressure sensor installed inside the cylindrical chamber will signal the 
control valve to the exempt pressurized fluid. As a consequence, the maximum impact gets attenuated by an additional four hydraulic legs and the lander may attain effective landing on Mars.

\section{MATHEMATICAL FORMULATION}

Here the area of the outer four landings legs is smaller that the inner four legs $\left(A_{2}>A_{1}\right)$ and this implies the force exerted on $F_{2}>F_{1}$. So, the velocity of hydraulic fluid moving across $\mathrm{A}$ is 1 and the velocity at $B$ is ${ }_{2}$. And the $\left(A_{2}>A_{1}\right)$ reflects that $\left({ }_{2}<{ }_{1}\right)$. Hence from the equation of continuity $a_{11}=a_{2}$, where $a=$ const.

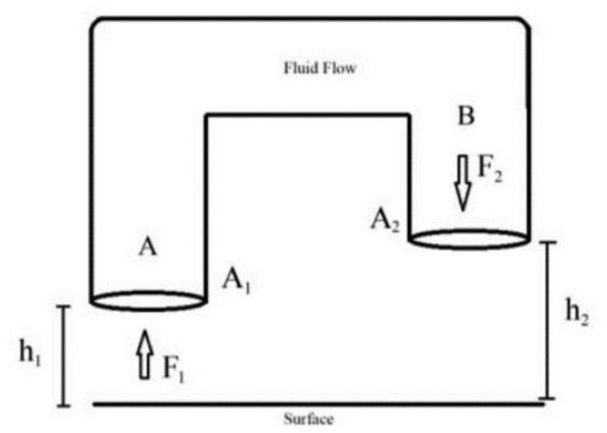

Figure 4. Free Body Diagram of Leg Interlink.

Further, the force acting on the fluid at A equals $P_{1} a_{1}$ and the force acting on fluid at $\mathrm{B}$ equals $P_{2} a_{2}$. Similarly, the work done on the fluid at A equals $P_{1} a_{1}{ }_{1}=P_{1} V$ and the work done by the liquid at B equals $P_{2} a_{2}{ }_{2}=P_{2} V$, where $P_{1}=\frac{F_{1}}{\mathrm{~A}_{1}}, P_{2}=\frac{F_{2}}{\mathrm{~A}_{2}}$.

Evaluating the work done per second by the pressure energy relation which equals $P_{1} V \quad P_{2} V$. Additionally, the increase in kinetic energy over landing can be expressed as

$$
\left[\begin{array}{llll}
\frac{1}{2} m_{2} & 2 & \frac{1}{2} m_{1}^{2}
\end{array}\right],
$$

and the increase in potential energy can be expressed as $m g h_{2} \quad m g h_{1}$.

Applying work-energy principle over work done, kinetic and potential energy, we get two force equations for $F_{1}$ and $F_{2}$ :

$P_{1} V \quad P_{2} V=\left(\begin{array}{ll}m g h_{2} & m g h_{1}\end{array}\right)+\left(\begin{array}{ccc}\frac{1}{2} m_{2}^{2} & \frac{1}{2} m_{1}^{2}\end{array}\right) \Rightarrow\left[\begin{array}{l}\left.F_{1}=P_{2} \mathrm{~A}_{1}+\frac{m \mathrm{~A}_{1}}{V}\left[\begin{array}{ll}g\left(h_{2}\right. & h_{1}\end{array}\right)+\frac{1}{2}\left(\begin{array}{cc}2 & 2 \\ 2 & 1\end{array}\right)\right], \\ F_{2}=P_{1} \mathrm{~A}_{2}\end{array} \frac{m \mathrm{~A}_{2}}{V}\left[\begin{array}{ll}g\left(h_{2}\right. & \left.h_{1}\right)+\frac{1}{2}\left(\begin{array}{cc}2 & 2 \\ 2 & 1\end{array}\right)\end{array}\right]\right.$,

The Equation (1) shows that the force exerted over $F_{2}$ and $F_{1}$. 


\section{MATERIALS}

\section{Helical Compression Springs}

In the primary unit, we prefer to use helical-compression springs as primary shock-absorbing material, it is because the compression spring has the ability to store and release energy substantially delivered by the lander in the axial direction during the terminal descent phase. It is supposed to absorb instant shock and deliver to the secondary unit. The strength of the spring depends on spring constant $(\mathrm{k})$ which ultimately depends on mass and forces exerted by lander modules. Subject to the type of material and gravity of Mars, the strength of the compression spring varies. Among various spring alloys, we propound to use a specific type (SWOSC-V) Silicon-Chromium Oil Tempered Wire named by Japanese Society of Spring Engineers. It has a high tensile strength ranging from $2010 \mathrm{MPa}$ to $2160 \mathrm{MPa}$ having temperature tolerance ranging from $400^{\circ} \mathrm{C}$ to $450^{\circ} \mathrm{C}$ (Reference 7). So, it will play a significant role in maintaining balanced forces between the lander module and the planetary surface of Mars. It also possesses mechanical characteristics.

Table 3. Mechanical Characteristics of Si-Cr Oil Tempered Wire*.

\begin{tabular}{l|l|l}
\hline S.No & Characteristics & Value \\
\hline 01. & Yield point & 1820 \\
\hline 02. & Elastic Limit & 1690 \\
\hline 03. & Yield Ratio & 90.7 \\
\hline 04. & Elastic Limit Ratio & 83.9 \\
\hline 05. & Young Modulus & $203 \mathrm{GPa}$ \\
\hline 06. & Tensile Strength & $2010-2160 \mathrm{MPa}$ \\
\hline 07. & Temperature Range & $400^{\circ} \mathrm{C}$ to $450^{\circ} \mathrm{C}$ \\
\hline 08. & Holding Time & $20-30$ minutes \\
\hline
\end{tabular}

\section{Hydraulic Fluid}

Hydraulic fluids such as mineral oil, water, emulsions, water-based glycols, synthetic fluids and ecologically acceptable fluids. Among these fluids, most of the hydraulic system uses mineral oil as their major constituent of hydraulic fluid. We prefer to use a particular type of HV-Mineral oil with the addition of extra additives such as viscosity improvers. It can accomplish all the requirements except 'fire-resistance' (Reference 8) with fluid density range from 0.8 to $0.9 \mathrm{~g} / \mathrm{ml}^{\dagger}$.

\section{EDL PERFORMANCE AND APPLICATIONS}

\section{Atmospheric Entry}

The descent vehicle is excogitated to enter from Martian orbit to minimize the entry velocity rather than direct entry. It is the safest approach for manned and large scale landing. It eliminates difficulties such as atmospheric and environment hindrance like dust storms that can be predicted

\footnotetext{
* Yamada, Y., \& Kuwabara, T. (2007). Materials for springs. Springer Science \& Business Media.

$\dagger$ Hydraulic Oil Density. Accessed from https://sciencing.com/hydraulic-oil-density-6052242.html on 30 Sep 2020.
} 
in advance by various Mars orbiters and it will allow us for effective preparation for Mars atmospheric entry (Reference 9).

\section{Descent}

The entry phase is followed by a descent phase, where the lander undergoes faster aerocapture by the rapid action of parachute deployment and Hypersonic Inflatable Aerodynamic Decelerator. Using the Viking technology NASA had landed the largest mass up to $900 \mathrm{~kg}$ of Mars Science Laboratory. It used a $70^{\circ}$ Spherical cone shell with a diameter of $4.5 \mathrm{~m}$ (References 10 and 11). But, the need to increase the diameter of aeroshell to decrease the ballistic coefficient and faster aerocapture is limited due to the availability of launch vehicles (concerns in enclosing within the payload fairing cone). To rectify this situation Hypersonic Inflatable Aerodynamics Decelerators can be employed for faster aerocapture during the descent phase.

\section{Landing}

After successful descent, the lander undergoes a landing phase where the novel legs will be deployed to rest the lander on the surface of Mars. Due to the effective design of the lander, the legs were in a deployed position and restricts the use of leg deployment events. Our EDL follows vertical landing for un-deployable legs. Now the lander gets successfully descended on the surface with the aid of novel impact intriguer.

\section{Applications}

This novel method of impact attenuation system will enable safe and large scale mass landings on the surface of Mars. It was devoid of the use of expensive retropropulsive systems thereby promoting cost-efficient landing on Mars. It has very good shock absorption capacity and the shock absorption capacity and can vary in accordance with the size, density of the hydraulic fluid, and the spring constant defined during fabrication. We hope that it may have excellent applications shortly for future human Mars exploration missions and large scale cargo missions. Some of the future proposals lander mission understudy is mentioned in the Table 4, which expresses the future of this novel leg.

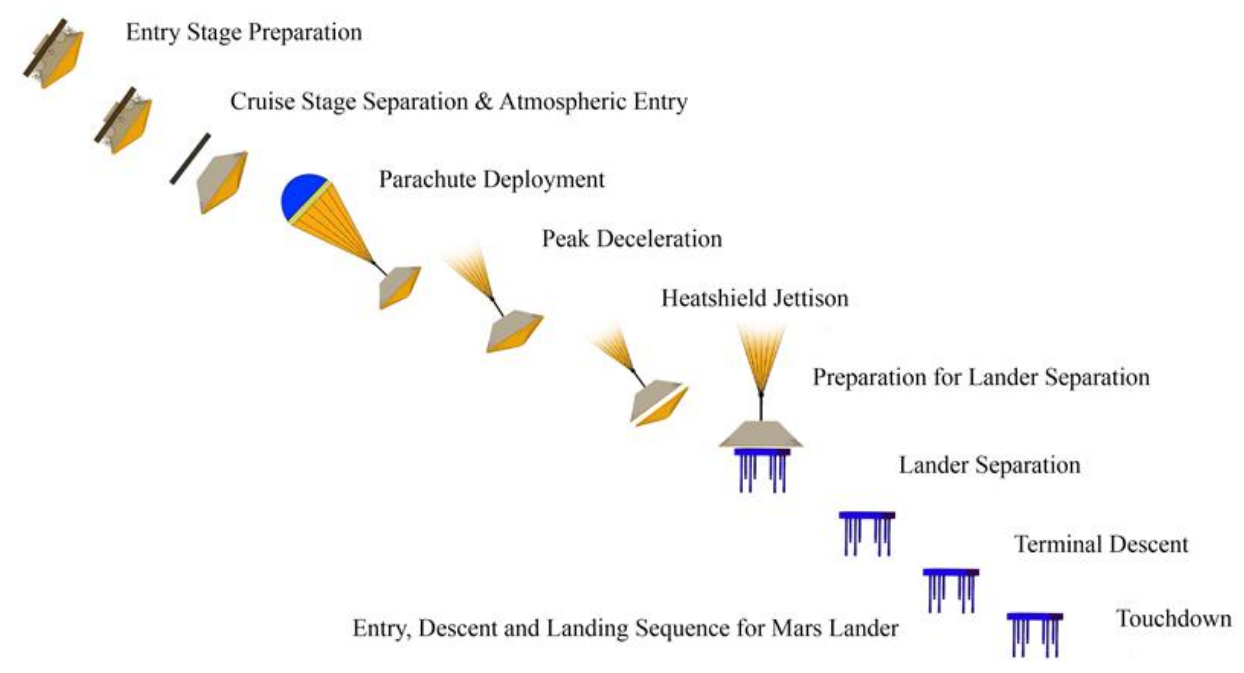

Figure 5. Outline Map of Complete EDL Scenario of Mars Lander. 
Table 4. Lander Proposals under Study*.

\begin{tabular}{l|l|l|l|l}
\hline S.No & Name & Country & Agency & Type \\
\hline 01. & Icebreaker Life & United States & NASA & Lander \\
\hline 02. & Martian Moon Exploration & Japan & JAXA & Lander and Sample Return \\
\hline 03. & Phootprint & Europe & ESA & Lander and Ascent Stage \\
\hline 04. & Fobos-Grunt (Repeat) & Russia & ROSCOSMOS & Lander and Ascent Stage \\
\hline 05. & Mars-Grunt & Russia & ROSCOSMOS & Orbiter and Lander \\
\hline 06. & BOLD & United States & NASA & $6-$ Impact Landers \\
\hline
\end{tabular}

\section{PRELIMINARY RESULTS}

From the formulations and analysis, we have estimated the terminal velocity of the lander (shown in Figure 6) at an altitude of 10 meters from the surface of Mars with drag coefficient $\mathrm{C}_{\mathrm{D}}=1.7$ and aeroshell reference area $\mathrm{A}=63.58 \mathrm{~m}^{2}$ (Diameter $=4.5 \mathrm{~m}$ ) and acceleration $\mathrm{g}=3.71 \mathrm{~m} / \mathrm{s}$ as constant; the impact force when the lander (shown in Figure 7) hits the ground; the potential and kinetic energy of the lander (shown in Figure 8); the drag force acted on the landing capsule during descent phase (shown in Figure 9); the total mechanical energy acted on a lander (shown in Figure 10); , and finally the pressure created within the hydraulic cylinder (shown in Figure 11); at $\mathrm{A}_{2}$ area of the exterior cylinder and pressure at $\mathrm{A}_{1}$ area of the interior cylinder (here the diameter of the cylindrical piston is considered as $0.2 \mathrm{~m}$ for exterior cylinder and $0.1 \mathrm{~m}$ for interior cylinder leg). Additionally, we have catalogued the EDL parameters of Mars landers in table 5.

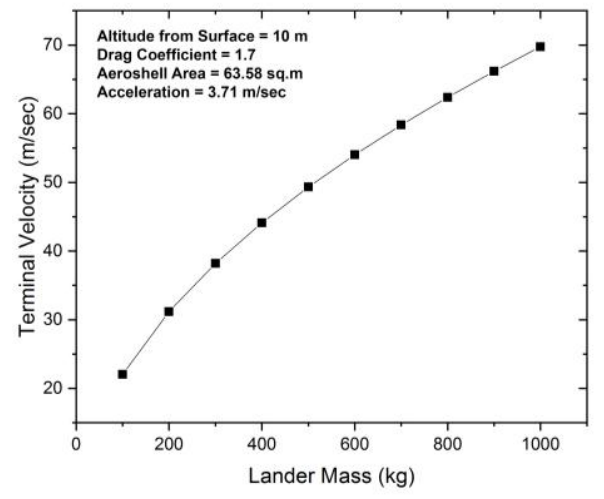

Figure 6. Terminal Velocity $(\mathrm{m} / \mathrm{s})$.

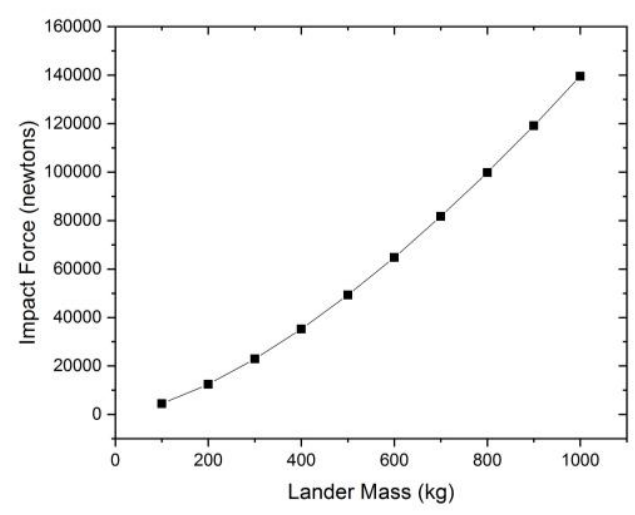

Figure 7. Impact Force (N).

*arXiv:1809.00062v2 [physics.pop-ph] 
Table 5. Comparative EDL Summary of Mars Landers (Reference 12)1.

\begin{tabular}{|c|c|c|c|c|c|c|c|c|c|c|c|c|c|c|c|c|}
\hline Parameters & Mars 2 & Mars 3 & Mars 6 & Mars 7 & Viking-1 & Viking-2 & $\begin{array}{l}\text { Phobos } \\
1 \text { and } 2 \\
\end{array}$ & MPF & Mars 96 & $\begin{array}{c}\text { Mars } 96 \\
\text { Penetrator }\end{array}$ & MPL & Beagle 2 & $\begin{array}{l}\text { Deep } 2 \\
\text { Space }\end{array}$ & $\begin{array}{l}\text { Phoenix } \\
\text { Lander }\end{array}$ & $\begin{array}{l}\text { Schiaparelli } \\
\text { EDM }\end{array}$ & InSight \\
\hline Entry Mode & direct & direct & direct & direct & orbit & orbit & direct & direct & direct & Direct & direct & direct & direct & direct & direct & direct \\
\hline $\begin{array}{c}\text { Entry } \\
\text { Velocity }\end{array}$ & & & & & 4.61 & 4.74 & - & 7.26 & 5.75 & 4.9 & 6.91 & 5.63 & & 5.59 & & \\
\hline $\begin{array}{l}\text { Relative } \\
\text { Entry } \\
\text { Velocity } \\
\end{array}$ & 6.0 & 5.7 & 5.6 & 1.2 & 4.42 & 4.48 & - & 7.48 & 4.9 & 4.6 & 6.80 & 5.40 & 6.9 & 5.67 & 5.83 & 6.3 \\
\hline $\begin{array}{l}\text { Peak Heat } \\
\text { Velocity }\end{array}$ & & & & & 4.02 & 4.0 & - & 6.61 & & - & & 4.70 & 5.94 & & & \\
\hline Aeroshell & $\begin{array}{c}120^{\circ} \\
\text { break } \\
\text { cone }\end{array}$ & $\begin{array}{l}120^{\circ} \\
\text { break } \\
\text { cone } \\
\end{array}$ & $\begin{array}{l}120^{\circ} \\
\text { break } \\
\text { cone }\end{array}$ & $\begin{array}{c}120^{\circ} \\
\text { break } \\
\text { cone }\end{array}$ & $\begin{array}{l}70^{\circ} \text { Sphere } \\
\text { Cone }\end{array}$ & $\begin{array}{l}70^{\circ} \text { Sphere } \\
\text { Cone }\end{array}$ & - & $\begin{array}{l}70^{\circ} \text { Sphere } \\
\text { Cone }\end{array}$ & $\begin{array}{l}\text { Blunt } \\
\text { Ended } \\
\text { Cone }\end{array}$ & $\begin{array}{l}\text { Blunt } \\
\text { Ended } \\
\text { Cone }\end{array}$ & $\begin{array}{l}70^{\circ} \text { Sphere } \\
\text { Cone }\end{array}$ & $\begin{array}{c}60^{\circ} \\
\text { Sphere } \\
\text { Cone } \\
\end{array}$ & $\begin{array}{c}45^{\circ} \\
\text { Sphere } \\
\text { Cone }\end{array}$ & $\begin{array}{l}70^{\circ} \text { Sphere } \\
\text { Cone }\end{array}$ & $\begin{array}{l}70^{\circ} \text { Sphere } \\
\text { Cone }\end{array}$ & $\begin{array}{l}70^{\circ} \text { Sphere } \\
\text { Cone }\end{array}$ \\
\hline Base Area & & & & & 9.65 & 9.65 & - & 5.52 & & & & 0.62 & & & & \\
\hline $\begin{array}{c}\text { Ballistic } \\
\text { Coefficient }\end{array}$ & & & & & 64 & 64 & - & 62.3 & & & 65 & 69.9 & 36.2 & 70 & 82 & \\
\hline Entry Mass & 1210 & 1210 & 635 & 635 & 992 & 992 & 2600 & 584 & 120.5 & 45 & 487 & 72.7 & & 603 & 577 & 608 \\
\hline Mass & 358 & 358 & 635 & 635 & 590 & 590 & 6220 & 361 & 3159 & 88 & 583 & 33.2 & 2.4 & & 577 & 727 \\
\hline $\begin{array}{l}\text { Aeroshell } \\
\text { Diameter }\end{array}$ & 3.2 & 3.2 & 3.2 & 3.2 & 3.5 & 3.5 & - & 2.65 & 1 & 0.29 & 2.4 & 0.93 & & 2.65 & 2.4 & 6.1 \\
\hline $\begin{array}{l}\text { Parachute } \\
\text { Diameter }\end{array}$ & & & & & 16 & 16 & - & 12.5 & - & & & 10.4 & & 11.5 & 12 & \\
\hline $\begin{array}{l}\text { Parachute } \\
\text { Drag }\end{array}$ & & & & & 0.67 & 0.67 & - & 0.4 & - & & & 0.92 & & 0.62 & & \\
\hline $\begin{array}{l}\text { Lift/ Drag } \\
\text { ratio }\end{array}$ & & & & & 0.18 & 0.18 & - & 0 & - & & & $2^{\circ}$ & & 0 & 0 & \\
\hline $\begin{array}{l}\text { Vertical } \\
\text { Velocity }\end{array}$ & & & & & 2.4 & 2.4 & - & 12.5 & 0.02 & 0.075 & 2.4 & & & 2.4 & & 2.3 \\
\hline $\begin{array}{l}\text { Landing } \\
\text { Legs }\end{array}$ & Ring & Ring & Ring & Ring & 3 & 4 & - & 0 & Ring & & 3 & 0 & 0 & 3 & 0 & 3 \\
\hline $\begin{array}{l}\text { Touchdown } \\
\text { Mass }\end{array}$ & 358 & 358 & 635 & 635 & 590 & 590 & - & 360 & 30.6 & 4.5 & 423.6 & 33.2 & 2.4 & 364 & 280 & 360 \\
\hline $\begin{array}{c}\text { Touchdown } \\
\text { Velocity }\end{array}$ & & & 0.06 & & 2.4 & 2.4 & - & 12.5 & 0.02 & 0.075 & 2.4 & & 0.17 & 2.4 & 0.15 & \\
\hline $\begin{array}{c}\text { Attenuator } \\
\text { Material }\end{array}$ & $\begin{array}{l}\text { Foam } \\
\text { Plastic }\end{array}$ & $\begin{array}{c}\text { Foam } \\
\text { Plastic }\end{array}$ & $\begin{array}{l}\text { Foam } \\
\text { Plastic }\end{array}$ & $\begin{array}{l}\text { Foam } \\
\text { Plastic }\end{array}$ & $\begin{array}{l}\text { Aluminium } \\
\text { honeycomb }\end{array}$ & $\begin{array}{l}\text { Aluminium } \\
\text { honeycomb }\end{array}$ & $\begin{array}{l}\text { Foam } \\
\text { Plastic }\end{array}$ & Air-bags & Air-bags & $\begin{array}{c}\text { Inflatable } \\
\text { Ballute }\end{array}$ & $\begin{array}{l}\text { Aluminium } \\
\text { honeycomb }\end{array}$ & Air-bags & $\begin{array}{c}\text { Hard } \\
\text { Lander }\end{array}$ & Crushable & $\begin{array}{l}\text { Crushable }-\mathrm{Al} \\
\text { Sanwich with } \\
\text { carbon fiber }\end{array}$ & Crushable \\
\hline Landing Site & $\begin{array}{l}45^{\circ} \mathrm{S} \\
47^{\circ} \mathrm{E} \\
\end{array}$ & $\begin{array}{c}45^{\circ} \mathrm{S} \\
202^{\circ} \mathrm{E} \\
\end{array}$ & $\begin{array}{c}23.90^{\circ} \mathrm{S} \\
19.42^{\circ} \mathrm{W} \\
\end{array}$ & - & $\begin{array}{l}22.27^{\circ} \mathrm{N} \\
47.95^{\circ} \mathrm{W} \\
\end{array}$ & $\begin{array}{c}47.64^{\circ} \mathrm{N} \\
225.71^{\circ} \mathrm{W} \\
\end{array}$ & - & $\begin{array}{c}19^{\circ} 7 \mathrm{~N} \\
33^{\circ} 13 \mathrm{~W} \\
\end{array}$ & $\begin{array}{c}41^{\circ} 31 \mathrm{~N} \\
153^{\circ} 77 \mathrm{~W} \\
\end{array}$ & - & $76^{\circ} \mathrm{S} 195^{\circ} \mathrm{W}$ & $\begin{array}{l}11.53^{\circ} \mathrm{N} \\
90.43^{\circ} \mathrm{E} \\
\end{array}$ & $\begin{array}{c}73^{\circ} \mathrm{S} \\
210^{\circ} \mathrm{W} \\
\end{array}$ & $\begin{array}{l}68.22^{\circ} \mathrm{N} \\
125.7^{\circ} \mathrm{W} \\
\end{array}$ & $\begin{array}{l}6.208^{\circ} \mathrm{W} \\
2.052^{\circ} \mathrm{S} \\
\end{array}$ & $\begin{array}{c}4.5^{\circ} \mathrm{N} \\
135.0^{\circ} \mathrm{E} \\
\end{array}$ \\
\hline MOLA & - & - & - & - & -3.5 & -3.5 & - & -2.5 & - & - & -3.0 & - & - & -3.5 & 1.45 & -2.5 \\
\hline
\end{tabular}

${ }^{1}$ Biswal M, Malaya Kumar \& Annavarapu, Ramesh Naidu. (2019). Comparative EDL Summary of Mars Ganders. 10.13140/RG.2.2.13568.07682. Accessed from https://www.researchgate.net/publication/330349539_Comparative_EDL_Summary_of_Mars_Landers. 


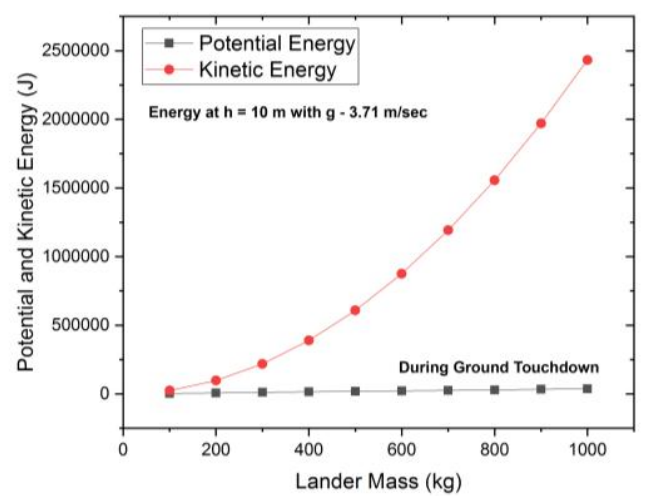

Figure 8. Potential and Kinetic Energy (J).

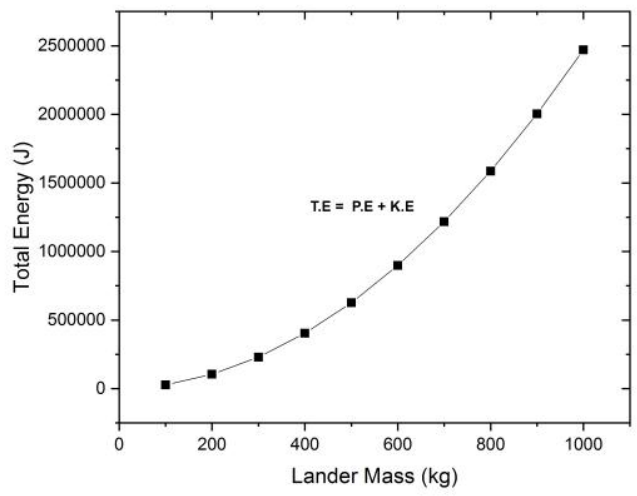

Figure 10. Total Energy of Lander(J).

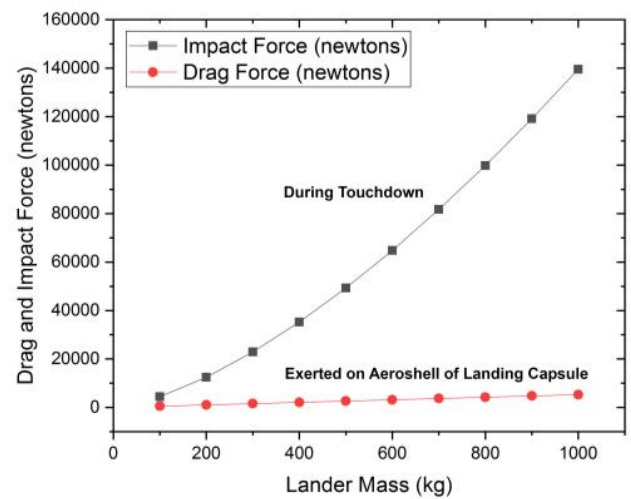

Figure 9. Impact and Drag Force $(\mathbf{N})$.

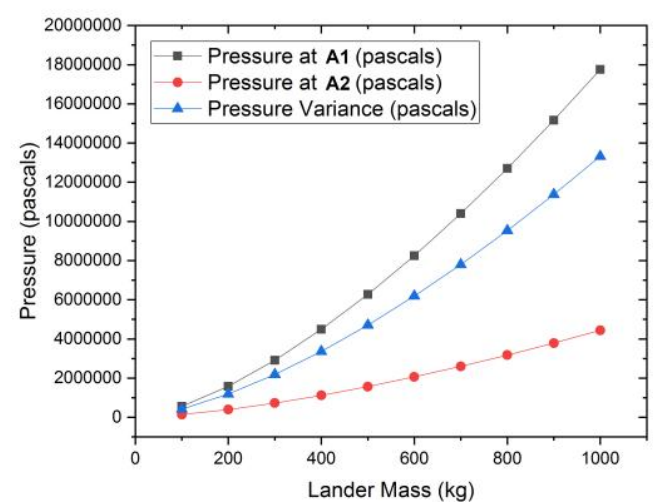

Figure 11. Pressure level of Hydraulic Leg (Pa).

\section{CONCLUSIONS}

Considering the demand for landing mechanism for future Mars and extraterrestrial exploration, we have proposed a dynamic Mars lander with sterling impact attenuator to land 0.2-1.0-ton lander. Further, we have extended our discussion to fabrication engineering and fluid dynamics with robust materials. Finally, from the quantitative analysis and formulations, we have displayed some preliminary results obtained so far. Complete dimensional analysis and dynamic simulation for this prototype will be studies in another paper. Besides, we hope that our proposed lander may overcome the challenges concerning turbulent or hard landing or crew or cargo lander mission through the next decade.

\section{ACKNOWLEDGEMENTS}

The authors would like to thank Dr. Ahmed Sahinoz from Sabanci University for providing Solidworks software packages. Also, we would like to extend our sincere thanks to my colleague K Priyanga, an M.Sc. Graduate from Department of Physics, Pondicherry University for aiding in deriving mathematical formulation for the lander.

\section{CONFLICT OF INTEREST}

The authors have no potential conflict of interest to report. 


\section{DEDICATION}

I (Malaya Kumar Biswal) would like to dedicate this paper to my beloved mother late. Mrs. Malathi Biswal for her motivational speech and emotional support throughout my life.

\section{ACRONYMS}

$\begin{array}{lll}\text { EDL } & - & \text { Entry, Descent and Landing } \\ \text { EDM } & - & \text { Entry Demonstration Module } \\ \text { ESA } & - & \text { European Space Agency } \\ \text { HIAD } & - & \text { Hypersonic Inflatable Aerodynamic Decelerator } \\ \text { JAXA } & - & \text { Japanese Aerospace Exploration Agency } \\ \text { LEO } & - & \text { Low Earth Orbit } \\ \text { MPF } & - & \text { Mars Pathfinder } \\ \text { NASA } & - & \text { National Aeronautics and Space Administration } \\ \text { ROSCOSMOS } & - & \text { State Corporation "ROSCOSMOS" } \\ \text { US } & - & \text { United States }\end{array}$




\section{REFERENCES}

[1] Biswal M, Malaya Kumar and Annavarapu, Ramesh Naidu (2020). Mars Missions Failure Report Assortment: Review and Conspectus. In AIAA Propulsion and Energy 2020 Forum. (p. 3541). https://doi.org/10.2514/6.2020-3541

[2] Biswal M, M. K., \& Annavarapu, R. N. (2021). A Study on Mars Probe Failures. In AIAA Scitech 2021 Forum (p. 1158).

[3] Braun, R. D., \& Manning, R. M. (2006, March). Mars exploration entry, descent and landing challenges. In 2006 IEEE Aerospace Conference (pp. 18-pp). IEEE.

[4] Schroeder, K., Bayandor, J., \& Samareh, J. A. (2016). Impact and Crashworthiness Characteristics of Venera Type Landers for Future Venus Missions. In 54th AIAA Aerospace Sciences Meeting (p. 0221).

[5] Benton, M. (2008, June). Crew and Cargo Landers for Human Exploration of Mars-Vehicle System Design. In 44th AIAA/ASME/SAE/ASEE Joint Propulsion Conference \& Exhibit (p. 5156).

[6] Biswal M, Malaya Kumar \& Annavarapu, Ramesh Naidu. (2018). A Novel Entry, Descent and Landing Architecture for Mars Landers.

[7] Yamada, Y., \& Kuwabara, T. (2007). Materials for springs. Springer Science \& Business Media.

[8] Hunt, T. M., Hunt, T., Vaughan, N. D., \& Vaughan, N. (1996). The hydraulic handbook. Elsevier.

[9] Biswal M, M. K., \& Annavarapu, R. N. (2021). Human Mars Exploration and Expedition Challenges. In AIAA Scitech 2021

Forum (p. 0628).

[10] Edquist, K., Dyakonov, A., Wright, M., \& Tang, C. (2009, June). Aerothermodynamic design of the Mars Science Laboratory heatshield. In 41st AIAA Thermophysics Conference (p. 4075).

[11] Bose, D., Santos, J. A., Rodriguez, E., White, T. R., \& Mahzari, M. (2013). Mars Science Laboratory Heat Shield Instrumentation and Arc Jet Characterization. In 44th AIAA Thermophysics Conference (p. 2778).

[12] Biswal M, Malaya Kumar \& Annavarapu, Ramesh Naidu. (2019). Comparative EDL Summary of Mars Landers.

10.13140/RG.2.2.13568.07682. 